\title{
READING DEUTERONOMY 22:22 IN JOHN 8:1-11: A CONTEXTUAL READING FROM AN AFRICAN- URHOBO PERSPECTIVE
}

\author{
John Arierhi Ottuh \\ Department of Christian Religious Studies \\ Obong University, Nigeria
}

\section{Abstract}

This paper focuses on reading Deuteronomy 22:22 in John 8:1-11 within the cultural context of the Urhobo people of Nigeria. Using a feminist hermeneutics approach, the aim of this paper is to examine how Deuteronomy 22:22 and John 8:1-11 constitute injustice to and oppression of women. The texts resonate with the Urhobo cultural narrative on sexuality in the similarity of treatment accorded women and men in both cultural milieus: the narrative of women's ordeals are established by the fact that women are accorded low status in both cultural settings. Drawing on existing literature and the selected texts, several nuances such as grammar, enactment and implementation, historical distortion and differing of intentions in Deuteronomy 22:22 and John 8:1-11 are also identified.

Key words: Deuteronomy 22:22; John 8:1-11; Contextualisation; African-Urhobo; Women; Men

\section{Introduction}

African biblical scholars have recently brought to the fore the need for Bible texts to engage in dialogue with contemporary society. Gerald West, drawing from Jonathan Draper's submission on the modern approach to African biblical scholarship, proposes a tri-polar approach which consists of: "the pole of the biblical text, the pole of the African context, and the pole of appropriation"(Draper 2001:148-168; West 2010:2131).Moreover, West, drawing from the comparative method of biblical interpretation in Africa proposed by Eric Anum, Justin Ukpong and Knut Holter, submits that “...African context and biblical text interpret each other" and that for dialogue or conversation to take place between text and context "a real flesh and blood African reader is required" (Anum 2000:468; Ukpong 2000:12; Holter 2002:88-89; West 2010:21-31).The focus of this paper is to read Deuteronomy 22:22 in John 8:1-11 and contextualise it in an AfricanUrhobo cultural milieu. Reading the texts shows that Deuteronomy 22:22 does not agree exactly with John 8:1-11 in terms of implementation. The two narratives address the issue of adultery and the punishment of offenders. However, there is a new development in the narrative in John 8:1-11. Although there is a claim that the events of John 8:1-11 did not occur at the time, the testimony of Deuteronomy 22:22 and other related scriptures in the Old Testament seem to authenticate that such a narrative would have taken place in the New Testament. It is, however, noteworthy that the authenticity of John 8:1-11 is contentious according to scholarly opinions. Some argue that John 7:538:11 was omitted (Metzger 1971:219-220; Gundry 1981:100; Alland 1981:273-274; Alexander and Alexander 1982:201). The omission of this pericope from earlier 
manuscripts could have been the result of scribes deliberately expunging it from the Fourth Gospel because it was liable to be understood as too indulgent of adultery (see also Metzger 1971:220). A number of scholars contend that the story may be historically true and must have been preserved in Christian oral tradition before interpolation into the canonical text (see also Gundry 1981:100,153). On the other hand, it is possible that this omission was a result of "lack of space on the missing leaves to include the section along with the rest of the text" and therefore this passage occurs after Luke 21:38 in some manuscripts, but is not an original part of Luke's gospel (see also Shepherd 1990:143-157).Although we cannot immediately conclude that Deuteronomy 22:22 authenticates John 8:1-11, there is evidence that such narratives existed in the Old Testament and during the time of Jesus. One example is the existence of dictates against adultery in ancient Jewish culture, which constituted a narrative in Jewish oral tradition (Metzger 1971:220).Further evidence is the similar storyline to that of Deuteronomy 22:22 in the story of Susanna (1-64) in the Apocrypha, another case in Jewish history. In the narrative in John 8:1-11, Jesus is seen as an imitation of Daniel who, in the story of Daniel and Susanna, comes to give judgment that reflects truth and equity (Daniel and Susanna 1-64).On the other hand, a parallel reading of Deuteronomy 22:22 and John 8:111 shows a discrepancy between what the vónos (nomos) says in the Old Testament and the actions of the scribes and Pharisees in response to the offence in John 8:1-11, which substitutes marginalisation, injustice and oppression of the woman caught in the act of adultery. This leads to the observation that women in ancient Jewish and African cultural milieus were and are oppressed in so many ways. Therefore, this paper intends to argue from the viewpoint of feminist liberation hermeneutics that the actions of the scribes and the Pharisees towards the woman caught in the act of adultery in John 8:1-11 were not a true interpretation of the vópos (nomos) in Deuteronomy 22:22.

Using the feminist hermeneutics approach, the aim of this paper is to examine how Deuteronomy 22:22 and John 8:1-11 constitute injustice to and oppression of women. This approach will reveal the warped reconstruction of the law that prescribed capital punishment for the act of adultery among the Jews. The feminist hermeneutic approach in African biblical hermeneutics is observed to be a diverse enterprise by modern scholars. For example, Wood (2013: iii) in her thesis notes that:

The study of feminist biblical hermeneutics is very diverse; it can mean different things to different people. As a result, there is much disagreement concerning how to read Scriptures from a feminist perspective in the correct way. For a proper study of the Scriptures from a feminist point of view, one must converse with other forms of feminist hermeneutics.

The diversity is quite obvious. However, the fact that Wood uses the model of Elisabeth Schüssler Fiorenza, Musa Dube and John Paul II does not solve the issue of the diversity of the feminine theology approach in biblical studies, but further deepens it, as scholars who approach the Bible from a feminine point of view may be influenced by their theological, denominational, cultural and social backgrounds. We can assume that every scholar who intends to use this approach in biblical studies is possibly reactionary depending on the contemporary status quo. This may be why Andrew Mbuvi submits 
that: "African Biblical Studies (ABS) can be characterized both as innovative and reactionary" (Mbuvi 2017:149-178). It is innovative in the sense that "it refuses to be confined by the methodologies, ancient concerns, and principles that govern biblical studies in the 'west' ... and instead charts a course that is more interested in making biblical interpretation relevant to present realities" (Mbuvi 2017:149-178). On the other hand, it is reactionary because "its driving force is partly a critique of the inadequacy of western biblical studies in providing meaningful responses to concerns that are pertinent to African communities" (Mbuvi2017:149-178).Justin Ukpong, an important proponent of inculturation hermeneutics, takes this line of thought further by clarifying the intended approach in African biblical hermeneutics. He explains that feminist hermeneutics seeks to use the Bible to fight against the oppression of women (Ukpong 1999:2-5).Proponents of feminist hermeneutics in African biblical scholarship also include Okure (1988:4759), Nasimiyu-Wasike (1992:101-118), Oduyoye (1994:38-53) and Akoto (2000:260277), whose works provide models for African feminist liberation hermeneutics.

\section{Conceptual clarification}

The book of Deuteronomy in the Old Testament and the Gospel of John in the New Testament represent Old and New Testament thoughts. Reading across these passages tends to open the mind to a duel perspective of the views of Deuteronomy and John's gospel. Deuteronomy is called the repetition of the Law because "the book contains a repetition of the Decalogue and of parts of Exodus" (Encarta 2009). On the other hand, the Gospel of John is seen by scholars as the book of signs (Palmer1999:11-13; Thomaskutty 2015:x) because it points to symbols and unfolds events in the mission of Jesus Christ. Therefore, what is meant by reading Deuteronomy 22:22 in John 8:1-11 is an attempt to view this particular narrative in the Gospel of John through the lens of Deuteronomy 22:22. The next concept to be clarified is the contextual reading of the Bible.

According to Tuesday Adamo, contextual reading of the Bible in African biblical scholarship "is the biblical interpretation that makes African social cultural context a subject of interpretation" (Adamo 1999:5; Adamo 2001:3). In the opinion of Alan John Meenan, "the biblical text ever remains the one constant factor in the discipline of hermeneutics. Yet the text does not exist in a vacuum, it speaks to a particular audience within a specific cultural context" (Meenan 2014:268).Moreover, Ukpong, a proponent of the comparative approach in Biblical interpretation in African biblical scholarship, demonstrates that "the actualisation of the theological meaning of the text in today's context is to forge integration between faith and life, and engender commitment to personal and societal transformation" (Ukpong 1999:24; Ukpong 2002: 17-32). These scholars illuminate the concept of contextual biblical study in Africa. That is, in this type of approach, the text and the context are brought into interaction through the visible human reader. In a narrower sense, what this means is that a contextual reading in the African perspective is the reading of the texts from the cultural perspective of the Urhobo people of Nigeria in relation to how a woman is treated if she commits adultery.

The Urhobo people are currently located in Delta State, Nigeria, in West Africa, although they lived in the former Mid-west region and in the Bendel State of Nigeria (Acquaye1974:525). The Urhobo constitutes the largest ethnic group in Delta State. They are spread over nine of the 25local government areas which make up Delta State: 
Ethipe West, Ethipe East, Ugheli South, Ugheli North, Okpe, Sapele, Udu, Uvwie and part of Warri South (Aweto and Igben 2003:11). The Urhobo occupy contiguous territory bounded by 'latitudes 5015' and 6' North and longitude 5040' and 6025' East" (Aweto and Igben 2003:12). They speak the Urhobo language. Although there is no official population figure that accurately details the ethnic population in Nigeria, past censuses, especially those of 1991 and 2002, indicate that the Urhobo population was over 1.1million and 2 million in their homeland and in Diaspora respectively (Akpomuvie 2009: 92-111). In 2005 the population of the Urhobo was estimated about 3 million (Ibodje 2009).According to this estimation, the Urhobo population grew at a rate of about 1 million in three years, and if it continued to grow at this rate, it is probably not less than 6 million in 2019. The Urhobo are very rich in cultural heritage and as such have developed thoughts, beliefs, religions, concepts, rich folklores and a work culture in their attempt to explain their environment and survive in it. They have codes or canons which guide behaviour and reasoning and are quoted profusely during speeches. However, I do not intend to explore these, because the focus here is to examine the issue of adultery and its punishment in the texts and Urhobo cultural setting; and how this constitutes oppression of women.

\section{Contemporary context of interpretation}

The contemporary context of interpretation is the situation of oppression of women in the Urhobo cultural milieu in terms of adultery and its punishment. As an eyewitness of the cultural setting of the Urhobo people of Nigeria, I have observed how women are treated unjustly in the Urhobo culture. It is common to excuse a man who has concubines, provided these women or girls are not married, but it is a taboo for a woman to hold the hand of a man who is not her husband, not to mention having sex with a bachelor or any other man not married to her (Ottuh 2014:63).The terms of punishment of adultery of woman are strict, with the goal of restraining married women from committing adultery. A man who commits adultery with another man's wife will be seriously punished too, but the punishment of the woman is more severe, as it forever taints her image and causes almost infinite stigmatisation. If a man retains such a woman as his wife, the stigma also extends to the man as the husband of an adulteress. This does not apply to the male counterpart. A man who commits adultery with another man's wife is severely punished, but after receiving the punishment, he continues with his life without any stigma. The woman, on the other hand, is blamed more than the man for acquiescing to sex with another man. This is why a woman who commits adultery is seen as "aye ro gbo farie", that is, a promiscuous woman, even if she had sex with only one man outside her marriage. This translates to considering her as igbelaja (a prostitute).

It is common practice to bring an adulteress before her husband and the elders (ekpako), but a male who commits the same offense, is not brought before his wife and the elders of the family. It is also a well-known fact in Urhobo culture that a man does not commit adultery unless he has sex with another man's wife. This is proven by the fact that a man is allowed to have a oshen (concubine), provided she is not married to another man, whereas a married woman is not even allowed to be held by the hand by another man, not to talk of her having a concubine. A woman may even know about her husband's concubine but has no power to oppose him in this. This practice is gradually dwindling in modern Urhobo society and it is unacceptable among Christians. However, 
among those who practice indigenous religion (African Traditional Religion), it still holds sway. It is even expected of a woman to allow her husband to marry other women because, in Urhobo culture, polygyny is a norm. This is even reflected in a song in Urhobo traditional folklore: "Aye rho guono ruoruo re, gbe no rovwe aye, rho guono ruoruo re gbe no rovwe, meaning "a wife who needs no other woman in the house should leave the marriage" (Ottuh 2014:63).A woman's insistence that she does not want another woman in her matrimonial home receives disapproval from family members, friends, and elders.

According to the Urhobo traditional belief, if a married woman commits adultery, erivwi (the spirit of the ancestors) will attack her and even kill her husband and her children, but this is not the case if a man commits adultery. The spirit of the ancestors and the gods seems to have tailored its support for a patriarchally inclined policy of polygyny. The controversy is further entrenched by the ruling that young girls must remain virgo intacta (virgin, that is unbroken hymen) till marriage, but it is not so for their male counterparts. Igbeladja (prostitute)status and family disgrace are the prospects of a girl who loses her virginity before her marriage, but her male counterpart who indulges in sex with several girls before marriage, is not seen as igbeladja.

In the Urhobo culture it is commonplace for a man to report his wife to the community and family elders if he suspects her of going out with another man. Such a woman is usually called in for questioning and expected to speak the truth under threat of the intervention of the gods and the ancestors. So, she will speak the truth to avoid invoking the gods and the ancestors, so that her children and husband will not be harmed by the spirits. On the other hand, a woman cannot report her husband to the elders if she is aware of her husband having a sexual relationship with another woman, because the man may have as many concubines as he wants provided, they were not married to other men.

This cultural narrative constitutes the contemporary context of interpretation of the texts in view, which has a parallel reading in John 8:1-11, a society that oppresses the woman caught in the act of adultery with cultural innuendos.

\section{The text}

\section{Deuteronomy 22:22}

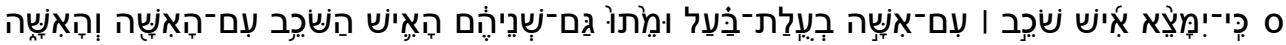

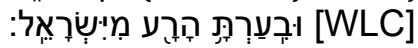

(If a man is caught lying with the wife of another man, both of them shall die, the man who lay with the woman as well as the woman. So you shall purge the evil from Israel [NRSV])

\section{John 8:1-11}

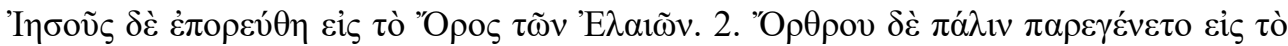

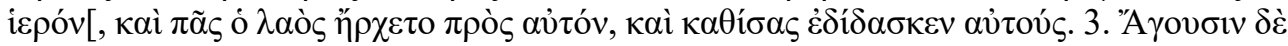

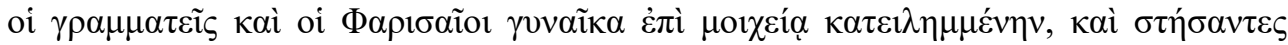

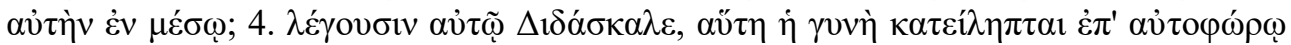

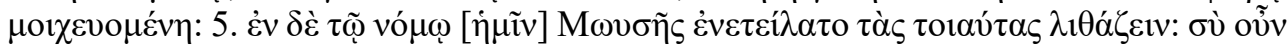

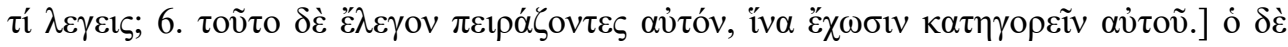

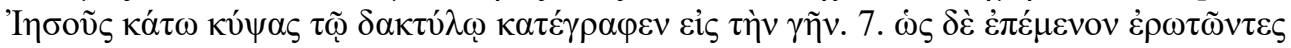




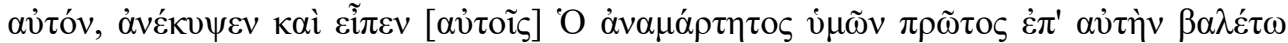

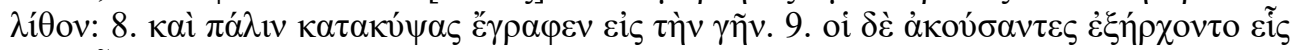

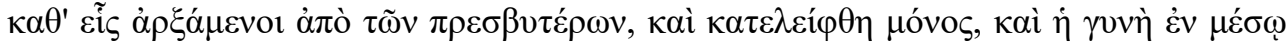

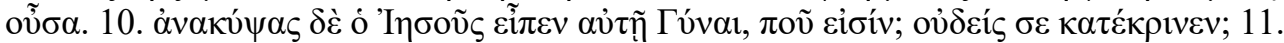

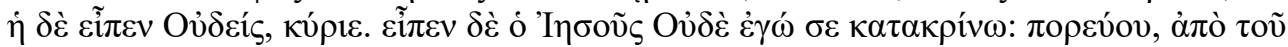

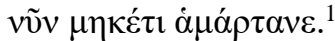

( 1 while Jesus went to the Mount of Olives. 2 Early in the morning he came again to the temple. All the people came to him and he sat down and began to teach them. 3 The scribes and the Pharisees brought a woman who had been caught in adultery; and making her stand before all of them, 4 they said to him, "Teacher, this woman was caught in the very act of committing adultery. 5 Now in the law Moses commanded us to stone such women. Now what do you say?" 6 They said this to test him, so that they might have some charge to bring against him. Jesus bent down and wrote with his finger on the ground. 7 When they kept on questioning him, he straightened up and said to them, "Let anyone among you who is without sin be the first to throw a stone at her." 8 And once again he bent down and wrote on the ground. 9 When they heard it, they went away, one by one, beginning with the elders; and Jesus was left alone with the woman standing before him. 10 Jesus straightened up and said to her, "Woman, where are they? Has no one condemned you?" 11 She said, "No one, sir." And Jesus said, "Neither do I condemn you. Go your way, and from now on do not sin again." [NRSV] $)^{2}$

\section{Genre of Deuteronomy 22:22 and John 8:1-11}

The Bible has been described as literature encompassing Old and New Testament literature. The Old Testament is also referred to as the Hebrew Bible. As literature the testaments fall into various literary genres. Literary scholar David Aune explains that "literary genres and forms are not simple neutral containers used as convenient ways to package various types of written communication but they are social conventions that provide contextual meaning for the smaller units of language and text they enclose" (Aune 1988:13). For Aune (1988), "the original significance that a literary text had for both author and reader is tied to the genre of that text, so that the meaning of the part is dependent upon the meaning of the whole". In simple terms literary genre tells a reader to which style or category literature, music or any other type of written or spoken discourse belongs. In particular, literary genre means a category of literary composition or endeavour (GradeSaver 2018).

The book Deuteronomy is derived from the LLX, suggesting a repetition of the law rather than a second law, as the word's etymology seems to suggest. Chaim Rabin, Samuel Leiter and Glenda Abramson say that Deuteronomy as one of the books of the Pentateuch is ancient Hebrew literature of the pre-exilian literature dated ca. 1200-587 BC (Rabin, Leiter and Abramson 2013). Rabin, Leiter and Abramson (2013) further explain that "the earlier prose texts were still very close to poetry in structure and language. The first real prose may well have been some of the laws recorded in the Pentateuch"'. Moreover, they submit that "in Jeremiah and Deuteronomy a high standard

Adopted from Interlinear Westcott \& Hort, WH Original Greek New Testament. Available online:

http://qbible.com/greek-new-testament/john/8.html. Accessed December 29, 2017.

2 Adopted from the New Revised Standard Version. 
of prose rhetoric was achieved: some of the conversations in the historical books were attempts to reproduce in writing the style of ordinary speech" (Rabin, Leiter and Abramson 2013). This corresponds with the submission of other scholars that see the book of Deuteronomy as a "written...farewell address by Moses to the Israelites before they entered the Promised Land of Canaan" (Young 2013). The address is said to have entailed "a recall of Israel's past, reiterating laws that Moses had communicated to the people at Horeb (Sinai), and emphasizing that observance of these laws is essential for the well-being of the people in the land they are about to possess" (Young 2013). In Deuteronomy 12-26, of which our text is part, the laws are reiterated, and the people are exhorted to obey. The section concludes with a report of the formulation of a covenant between God and his chosen people (Young 2013).

From the above, it is obvious that Deuteronomy can be located within a tripartite genre. The first is narrative, because it narrates how God has been good to Israel and the need to be faithful to Yahweh. Wilson Baroody and William Gentrup add their voices to this submission when they state that Deuteronomy "follows the pattern of narrative and legal combination as Moses recapitulates to the new generation their salvation history in chapters 1-11" (Baroody and Gentrup 2010:126-127).In chapter 31 the final brief narrative records Moses' death and eulogy, avowing that the people have finally "learned to obey divinely appointed leadership in the case of Joshua" (Baroody and Gentrup 2010:127).The second is prose; Deuteronomy deviates from poetry and resorts to speech delivery by Moses, a speech seen by some as a valedictory writing which was read to the Israelites as they prepared to enter the PT. According to Baroody and Gentrup (2010:128-133), the speech elaborates on the social significance of the law (Deut. 1230). The third is Torah(law). Deuteronomy is law because it belongs to the branch of Old Testament literature called Torah. In this case, it is a repetition of the Law of Moses. According to Richard J. Krejcir, the law entails the "instructions and precepts of God given to Israel through Moses, such as Leviticus and Deuteronomy" (Krejcir 2006).In the same vein, Raymond Westbrook says that "the bulk of the law in the Torah are thus concentrated in two main clusters...the first in Exodus 21 and 22:1-16... and the second cluster in Deuteronomy 21 and 22, has a central block that is divided by a group of ethical rules (22:1-12)..." (Westbrook 2008:100). Drawing from Sproul's (1977:90) definition of casuistic law as an expression that indicates a condition, such as "if...then", it is plausible to situate Deuteronomy 22:22 in the casuistic law because it states what should happen to a man and a woman who are caught in the act of adultery. The casuistic law acts as guideline for carrying out justice. In short, it has been established that Deuteronomy falls within a tripartite genre which includes narrative, prose and law.

On the other hand, John 8:1-11 falls within the genre of the gospels. The four gospels (Mark, Matthew, Luke, and John), according to Krejcir, "contain a bit of all the literary types with the primary purpose of expressing faith in Christ and what He has done on our behalf. In these works, the stories are not necessarily in chronological or sequential order, except for Luke" (Krejcir 2006). John 8:1-11 is a Pericope Adulterae- a narrative within a narrative. Chris Keith argues that the pericope presents Jesus as a person who can write and at the same time a person who knows the law (Keith 2009: 119140).Moreover, Keith (2009:1) states "that the claim that Jesus is capable of writing is an important key to understanding the insertion of (PA) into the Gospel of John (GJohn). It therefore offers a new interpretation and transmission-history of perhaps the most 
popular story in gospel tradition." The argument regarding the location of the pericope sometimes makes it difficult to locate it within the Gospel of John. However, Keith also presents at least three reasons to consider Pericope Adulterae's traditional location as its first location in what would become canonical tradition: "(1) John 7.53-8.11 is, by far, the majority location for PA in the manuscripts; (2) John 7.53-8.11 is the earliest demonstrable location for PA in both the manuscript tradition and extrabiblical citations of the story; and (3) of the late alternative locations, at least some are due to the impact of lectionary readings" (Keith 2009:119-139). Its location does not, however, affect its identity in terms of being a narrative, because such narrative is consistent with the Old Testament law as it concerns adultery. There is, undeniably, a twist in the narrative in the sense that the issue of adultery is presented to Jesus and at the same time, the issue of writing is also interpolated. It is not clear if that which is written relates to the subject matter, which is another reason to conclude that it is one narrative.

\section{Provenance of Deuteronomy 22:22 and John 8:1-11}

Provenance of biblical literature refers to the source of ownership of history or origin (that is, place of origin) of such material. Scholars observe that "until the 19th century, most Christians held that Deuteronomy was substantially Mosaic in origin, but when European liberal thinkers attack the Mosaic authorship of the Pentateuch systematically, Deuteronomy, known by that time as the D document was relegated to 7 th century B.C." (Bromiley 1979:935). Also, according to George L. Robinson, "certain modern critics since De Wette (1805) advocate a late origin of Deuteronomy, claiming that it was first published in $621 \mathrm{BC}$, when Hilkiah found 'the book of the law' in the temple in the 18th year of King Josiah (2Ki 22:8 ff)" (Robinson 1939). The theory goes further to say that "the kernel of Deuteronomy and 'the book of the law' discovered by Hilkiah are said to be identical" (Robinson 1939). For the proponent of Mosaic origin, it is plausible to agree that Deuteronomy fits into the formative period of Israel's history in the sense that the historical situation from first to last is that of Moses. Moreover, the references to foreign neighbours such as Egypt, Canaan, Amalek, Ammon, Moab and Edom are indications of Mosaic origin because these were nations which flourished in Moses' times (Robinson 1939). Deuteronomy 22:22 particularly fits the description of the Mosaic laws. One of the Mosaic Ten Commandments is the instruction not to commit adultery.

On the other hand, any exegete attempting to study John 8:1-11 must contend with the issue of its authenticity, especially its inclusion in its position in John's gospel. This raises the question of whether John 7:53-8:11 can be regarded as genuine, and if so, should it be included in the Fourth Gospel following 7:52? (Bible.org 2017). Among modern commentators and textual critics it seems to be a foregone conclusion that the section is not original but represents a later addition to the text of the gospel (Bible.org 2017). One of the commentators who rejects the originality of John 8:1-11 is Bruce M. Metzger. He says: "the evidence for the non-Johannine origin of the pericope of the adulteress is overwhelming" (Metzger 1971:219). There is also other external and internal evidence that rejects or supports the omission or inclusion of the text in the Johannine literature. The external evidence that throws light on its omission and inclusion, are: 
Omit 7:53-8:11: 66, 75, a, B, L, N, T, W, X, Y, D, Q, Y, 053, 0141, 0211, 22, 33, $124,157,209,565,788,828,1230,1241,1242,1253,2193$, etc. In addition codices $\mathrm{A}$ and $\mathrm{C}$ are defective in this part of John, but it appears that neither contained the pericope, because careful measurement shows that there would not have been enough space on the missing pages to include the pericope 7:53-8:11 along with the rest of the text. Include 7:53-8:11: D, F, G, H, K, M, U, G, 28, 700, 892, 1009, $1010,1071,1079,1195,1216,1344,1365,1546,1646,2148,2174$, etc. In addition $\mathrm{E}, \mathrm{S}, \mathrm{L}$, and $\mathrm{P}$ include part or all of the passage with asterisks or obeli, 225 places the pericope after John 7:36, 1 places it after John 21:24 or 25, and 13 after Luke 21:38.In evaluating this manuscript evidence, it should be remembered that in the Gospels A is usually considered to be of Byzantine text-type (unlike in the Pauline epistles, where it is Alexandrian), as are E, F, and G (which are of Western texttype in the Pauline epistles). This leaves D as the only major Western uncial witness in the Gospels. Therefore we could summarize the evidence by saying that almost all early manuscripts of Alexandrian text-type omit the pericope, while most manuscripts of Western and Byzantine text-type include it. But we must remember that "Western manuscripts here refers only to D, a single witness. Thus, it can be seen that practically all of the earliest and best manuscripts we possess omit the pericope; it is found only in manuscripts of secondary importance. But before we conclude that the passage was not originally part of the Gospel of John....(Bible.org 2017)

On the other hand, the internal evidence dwells on questions of style and content. Gordon Fee contributes that "contemporary critics generally agree that questions of internal evidence should usually be asked first and that the weight of the manuscripts evidence should be applied secondarily" (Fee 1993:15).Moreover, "scholars generally agree that the story of the woman caught in adultery was not originally part of the Gospel of John, but also believe that the story is truly an ancient one with earmarks of an authentic incident from Jesus' life" (Gench2009:398.).According to Armin Baum, the pericope's textual originality is defended among others by Burgon (1896:249-279),Hodges (1979:318-332) and Baum (2014:163). Baum's assertion of the authenticity of the pericope of the adulteress is based on the historicity of the event; he argues that the historicity of the event that the pericope adulterae (John 7:53-8:11) relates, has not been disproved. He further argues that "if the canonicity of the [pericope of the adulteress] is determined according to the same historical and content-related criteria that the ancient church applied during the development of the canon of Scriptures, then nothing speaks against its canonical status" (Baum 2014:163).Drawing on the above submissions, it is plausible to agree that John 8:1-11 is authentic because it is consistent with Jesus' teaching of forgiveness. Although the argument of the story is not contained in earlier gospel extant such as papyri $\mathrm{P}^{66}$ of ca. AD 200, the story is authentic in the sense that it is consistent with Jesus' teaching on forgiveness as related in the gospels. Rather than dwell on its placement, the validity of the story should be of paramount importance.

\section{Socio-historical context of Deuteronomy 22:22}

Determining the social and historical context of Old Testament literature is sometimes not easy. Deuteronomy 22:22 is such a passage. However, scholars provide us with 
insights in determining the socio-historical context of Deuteronomy. Cynthia Edenburg points out that Deuteronomy 22:22 belongs in the Deuteronomy family laws (Edenburg 2009:43-60).The laws in the Deuteronomic code constitute a guide for living meant to set the Israelites apart from other peoples, whether in the pre-exilic, exilic or post-exilic time (Ademiluka 2013:14). Sexual offenses vary in Hebrew culture and include bestiality (Ex. 22:19-20; Lev. 20:15-16; Deut. 27:21-22), adultery, incest (Deut. 23:1; Lev.18:9), homosexuality (Lev. 20:13; Deut. 23:17-18) and fornication (Deut. 22:13-30). The earliest version of this law is found in the Laws of Hammurabi and, like the biblical law in Deuteronomy 22:22, it lacks counter-cases dealing with mitigating circumstances such as rape (Edenburg 2009:43-60).All of these lead to corresponding punishment of both culprits depending on the gravity of the offense.

In the Deuteronomic Hebrew community, sex with an unbetrothed maiden was prohibited, but punishment was less severe than that for adultery (see Deut. 22:28-29). It is believed that "since she is not betrothed to another, it is possible to compel her assailant to marry her; the sum he is required to pay is considered the standard bride price, and he only forfeits his right of divorce" (Edenburg 2009:43-60).But sex with a betrothed maiden was subject to more investigation in order to determine whether the girl was a promiscuous person who had secretly been having sex with males. Therefore, the onus was on the woman to prove her innocence (Deut.22:23-29). The betrothed maiden who claimed to have been assaulted by a man, had to prove her innocence and if she could not, received the same judgment as a promiscuous girl, which could include execution by stoning (Edenburg 2009:Case 4; Deut.22:21,23).It was a common understanding among the Hebrew in the context of the Pentateuch that a girl "who wanders about the town on her own and who does not resist her assailant by crying out, is guilty of promiscuity (Sifre; Deut 242)" (Edenburg 2009:Case 4).If itwas established that she cried out and no one came to her rescue, she was exempted from punishment. In Jewish antiquity, a paramour of a married or a betrothed woman "was technically the adulterer (noef), and under the Biblical law suffered death together with the adulteress (noefet)" (Amram 1906). According to Amram:

under the theory of the Talmudists, which still further mitigated the severity of the law, the woman could not be convicted of Adultery until it was proved that she had been previously cautioned, in the presence of two witnesses, not to have any communication with the suspected man, and that, in spite of such caution, she had met him secretly under circumstances that would make the commission of the crime possible (Mishnah Soțah, is. 1, 2; Gem. 2b). This caution was given to her because of the general tendency of the rabbinical law toward mercy, based in this case on a technical interpretation of the Biblical text (Num. v. 13). (Amram 1906)

Moreover, "the punishment for this crime was stoning to death at the place of public execution (Deut. xxii. 24). The punishment for adultery according to the Mishnah (Sanh. xi. 1) was strangulation" (Amram 1906:216-218).In Jewish culture, a woman was expected to be a virgo intacta (virgin) before marriage. In the event that a girl got married and the husband made the allegation that she was not a virgin before he married her, she and her father were expected to prove her innocence. In the event that they were unable to prove her innocence, the woman would be stoned at the compound of the father. This 
matter-of-fact statement in the mishnaon Ketubot 2a speaks volumes about Talmudic attitudes toward premarital sex and female sexuality. A man acquiring a bride expected her to be a virgin -indeed, he paid a premium for virginity in the marriage contract, since a virgin received 200 dinars in alimony in the case of divorce, where a widow received only 100 dinars (Kirsch 2018; Reeder2013:122).For Kandy Queen-Sutherland, this special regulation placed on virgins was a result of a patriarchal-centred world where women bore more shame in the operation of this custom than men (QueenSutherland2016: 501-512).From this viewpoint it is not clear in the case of the adulteress in John 8:1-11 whether the woman caught in adultery falls into the category of betrothed or unbetrothed. This is one aspect that can be researched further.

\section{Analysis of Deuteronomy 22:22}

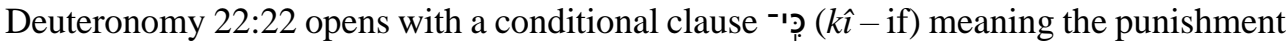

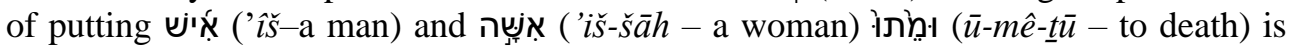

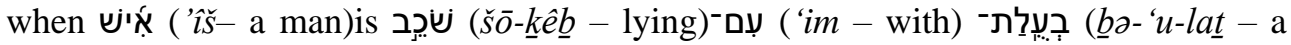

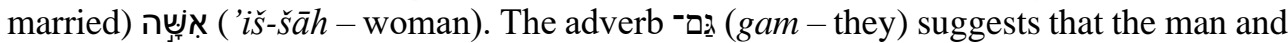
the woman should be regarded as culprits and be put to death at the same time. The term

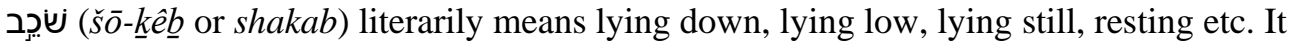
is used in the Qar imperfect tense, thereby suggesting a present-continuous action

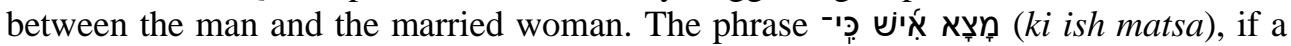
man be found or caught with another man's wife or betrothed, alludes to the point that

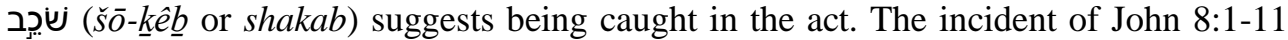
seems to follow this line of thought when the accusers of the woman say: " $1 \varepsilon \gamma v \pi \zeta \eta \lambda$

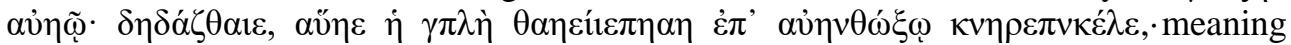
"Teacher, this woman was caught in the very act of committing adultery." In Jewish antiquity, the husband of the woman had a legal right to accuse his wife of adultery after one or two warnings to the woman to stop seeing any man he suspected of having an affair with his wife (Amram 1906:216-218). In Deuteronomy 22:22, the word נָארך (naaph - adultery) is not directly used. However, the context of the text suggests that

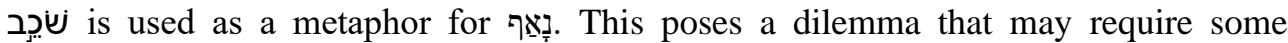
investigation. First, it seems to throw light on what is meant by שׁنِ when it refers to it as הרָרע . What is referred to as evil in the text if not adultery? Also, looking at the text from the viewpoint of the entire pericope, it refers to adultery. The punishment prescribed for the culprit in the text is stoning to death and it corresponds with the punishment prescribed for an adulterer and adulteress. Scholars indicate that the meaning of evil in this context "refers to deeds that contaminate society and damage its relationship to Yahweh" (Nelson 2004:171).It has also been established by scholars that in the grouping of Deuteronomy, "the entire second discourse of Moses (Deut. 5-26) is a single literary unit that convincingly demonstrates that the moral law informs the statutes, judgments and commands of God" (Kaiser Jr. 1983:129).Specifically, scholars also agree that Deuteronomy 22:9-23:18 belongs to the law regarding adultery (Kaufman 1978: 105-58; Merrill1994:217-336).Thomas L. Constable adds his voice to this argument when he clarifies that Deuteronomy 22:22 corresponds to the seventh commandment: "You shall not commit adultery" (5:18) (Constable 2017:97). For Constable, in the context of Deuteronomy 22:22, "adultery involves 'mixing' people in a way that they should not mix. The Israelites needed to keep things that were "properly 
apart' separate" (Constable 2017:97). Constable's submission aligns well with the

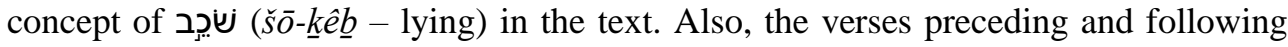
Deuteronomy 22:22 (the entire pericope concerning sexual regulations, Deut. 22:13-30) also suggest a meaning that is other than lying on, lying with, lying down, etc. Constable takes the argument further by proposing seven types of cases embedded in Deuteronomy 22:13-30:

The first case (vv. 13-19) is of a man who marries a woman and then, after consummating the marriage, falsely accuses her of being a harlot ("playing the harlot," v. 21; "not [being a] virgin" when he married her, v. 17; i.e., a promiscuous woman). If the girl could prove her virginity, her husband would have to pay a large fine (cf. 2 Sam. 24:24) to her father and remain married to the girl. The second case (vv. 20-21) involved a similar situation, but in this instance the girl was proven not to be a virgin. The young bride would suffer stoning for being a ("playing the") "harlot," a capital offense in Israel. These verses reveal that sexual intimacy before marriage is sinful, and very serious in God's sight (cf. 1 Cor. 7:1-2).The third case (v. 22) decreed that a man who committed adultery "with a married woman" would die along with the woman ("both of them shall die"). The fourth case (vv. 23-24) dealt with a man who had intercourse with an engaged girl in a city. Israelites regarded an engaged girl as virtually married, and even called the girl in this case "his neighbor's wife" (v. 24). Thus they treated the man as having committed adultery, as in case three. Both individuals would die by stoning. The girl died because she did not cry out for help; she consented to the act. Apparently Moses was assuming that if she had cried out, someone in the city would have heard and rescued her. The fifth case (vv. 25-27) involved a situation similar to case four, but the intercourse (rape in this case) took place in an isolated field. In this instance only the man died, assuming the girl "cried out" for help but no one heard her ("there is no sin in her worthy of death"). Presumably, if it was clear that she did not cry out, she could have been executed as well. The sixth case (vv. 28-29) had to do with a man and a "virgin" who had intercourse ("seizes her and lies with her"; "violated her"; a rape) before they became engaged. In this case they had to marry, and could not divorce. In addition, the man had to pay a penalty of "50 shekels of silver" to his new father-in-law (cf. Exod. 22:16-17). The seventh case (v. 30) Moses stated in terms of a general principle. God forbade incest in Israel. "Uncovering the skirt" is a euphemism for sexual intercourse in Scripture (27:20). To do this means to encroach on another person's marital rights. To "cover the skirt" in this sense, represents committing to marry (cf. Ruth 3:9). (Constable 2017:97-99)

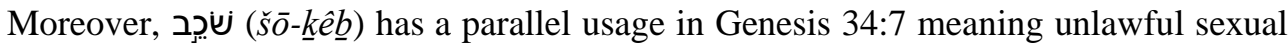
intercourse when Shechem the son of Hamor raped Dinah the daughter of Jacob. This shows that שe שe in Deuteronomy 22:22 means lying with another man's wife in terms of sexual intercourse. If we agree with the above submissions, we can accept that is a typical metaphor for (ָָאף (adultery). Scholars also identify adultery as a wilful act that crosses the boundary lines that protect another man's family. Legal stipulations within Deuteronomy call for the adulterer to be stoned - man and woman alike if she is married 
(Deut 22:22)" (Queen-Sutherland2016: 501-512). It, therefore, means that crossing this line is evil and deserves capital punishment as in the case painted in Deuteronomy 22:22. In the Old Testament adultery is also used metaphorically to mean apostasy in terms of syncretism or outright serving of other gods. According to Kandy Queen-Sutherland, "adultery is likewise paralleled in Jewish tradition with the command to have no other gods. This metaphorical use of adultery is a key theme of the prophets in decrying the nation's apostasy" (Queen-Sutherland2016: 501-512). Idolatry is also "identified as committing prostitution against Yahweh. This description is both in the Torah and Prophets" (Reeder 2013:135). In either case, it is equated with idolatry. It is also symbolic of "national unfaithfulness" (Reeder 2013:135). Particularly, the act of (šo $k \hat{k} \hat{e} \underline{b}$ - lying) with another man's wife or someone's betrothed was considered asserious רָ ( $\mathrm{ra}$ - evil) among Jews in the Pentateuch milieus. Etymologically the word רָ is derived from (ra'a'), meaning to break, spoil or break into pieces, hence the breaking of law, covenant or agreement, or the spoiling of something. In the Qar perfect, ער meansto be displeasing, to be sad, to be injurious, to be evil, to be wicked, to be evil bad (רָ Hebrew Dictionary Lexicon-Concordance). In general, רָ also means bad (physically, socially or morally). In the context of the text, רִ relates to adultery and the culprits receive capital punishment.

\section{A critical discussion from a feminist perspective}

The first issue for discussion at this point is the relationship between Deuteronomy 22:22 and John 8:1-11. At what point do we read Deuteronomy 22:22 in John 8:1-11 and John 8:1-11 in Deuteronomy 22:22? In Deuteronomy 22:22, the law of adultery is denoted in Hebrew cultural and religious contexts. On the other hand, in the narrative in John 8:111 , it is implemented. This is the only portion of the New Testament where Deuteronomy 22:22 is implemented. A parallel reading of the texts reveals some

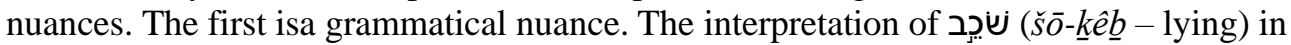
Deuteronomy 22:22 and Morxsía (moicheia - vv.3-4) have two different literary and

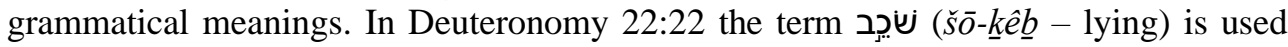
metaphorically to imply adultery. But in John 8:3-4 Morxeía is used directly to mean adultery. It refers to a woman who committed adultery. The phrase reads: $\gamma \pi \lambda \alpha i \tilde{\theta} \theta \alpha$

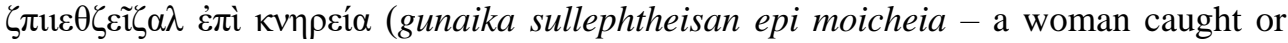

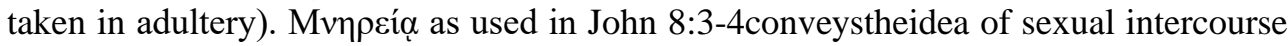
between a man and woman who are not husband and wife (Ottuh 2015).A second nuance is the fact that while the punishment in Deuteronomy 22:22 corresponds with the punishment for adultery in the Deuteronomy code, John 8:1-11 never says whether the woman is married, an unmarried virgin or a betrothed virgin. However, the punishment expected by the men who accuse the woman, seems to be in line with the Deuteronomy narrative of a man who accuses his wife of adultery, requiring the woman to prove her innocence, which resonates with the Deuteronomy 22:22 code. A third nuance is historical distortion. History is distorted when the men bring only the woman before Jesus with the claim that she and the man were caught in the act of adultery. Where the practice is enacted in the Old Testament, both the man and the woman are supposed to be stoned to death (Deuteronomy 22:22). The history is thus distorted by a paradigm shift, by twisting the practice around. The Deuteronomy narrative states that "if a man be found or caught with another man's wife", such man be stoned alongside with the 
woman. But in John 8:1-11 there is a paradigm shift which focuses the attention on the woman rather than the man. This is tantamount to injustice to and oppression of the woman. It would have been just if the man and the woman were brought to Jesus for punishment as stipulated in Deuteronomy 22:22. A fourth nuance is the difference of intentions. In Deuteronomy 22:22 the intention is to guard Israel against the sin of sexual impropriety in the community of Yahweh's worshippers, especially as they are about to settle down in the Promised Land. But in John 8:1-11 the intention is to commit wickedness against Jesus Christ. The answer to their request is like a double-edged sword that can cut both ways. If Jesus says that the woman should be stoned to death, He will be guilty of treasonable felony because the Jews had no powers to carry out capital punishment since they were under Roman authority at the time. And if He says she should not be stoned, He will be guilty of blasphemy by contradicting the Law of Moses. Moreover, if He approves the stoning of the woman, His preaching about love and forgiveness of sin will also be jeopardised.

The second issue for discussion here is Jesus' response to the accusers of the woman in John 8:1-11. Jesus' answer to the question suggests justice, forgiveness and cultural

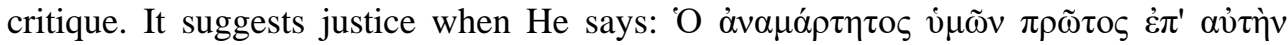
$\beta \alpha \lambda \dot{\varepsilon} \tau \omega \lambda i \theta$ ov (the one without sin among you should cast the first stone). In ancient Juda the principle accuser as a witness had to cast the first stone at the transgressor followed by the next witness until the last person (Penner2003:1-2; Ngewa2003:147).It wasbelieved that if the accusations were false, the blood of the victim would be upon the head of the principle witness. So if the principle witness does not cast a stone, neither can the other witnesses. And should the accusation be unfair, this person will receive the punishment of the innocent person. ${ }^{3}$ So how does Jesus' response suggest justice? First, the reaction of the accusers (the scribes and the Pharisees) depicts guilt and injustice. Rather than stoning the woman accordingly, they drop their stones and leave one after the other, because they were as guilty as the woman. Second, the man who committed the sin of adultery with the woman is not brought forward with the woman, a situation which suggests that the man may have been allowed to escape despite committing the offence with the woman. Jesus' response reveals this oppression of the woman in that the man who committed the same sin, was allowed to escape. Although, we were not told what happened to the man in the narrative, it is plausible to think that the man was

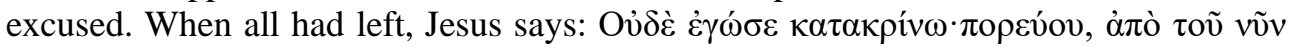
$\mu \eta \kappa \varepsilon ́ \tau \imath ~ \alpha ́ \alpha \alpha ́ \rho \tau \alpha v \varepsilon$ (I do not condemn you either, go and do not sin again). Jesus shows mercy but does not condone her sin. Her sin is not forgiven on the basis of her being a woman, but with the affirmation that adultery is a sin irrespective of gender, but the sinner needs to repent. All of them, the woman, the man, the scribes and the Pharisees need to repent of sin. Moreover, Jesus' response also suggests cultural critique and as such could be adopted as a paradigm in contemporary African societies to correct bad cultural practices. The socio-narrative in Deuteronomy 22:22 to John 8:1-11 shows how women have been victims of patriarchal cultural systems. Jesus, a man in this instance,

In the Pentateuch, especially aspects of the Torah, the stipulations for witnesses are made clear. See for instance Exodus 20:16 and Deuteronomy 19:16-21. In Numbers 31:15-18 Moses, after exacting revenge on the Midianites, reiterates the punishment of stoning for sexual misconduct especially adultery, but this must be based on evidence presented by witnesses. For more details see Gower (1983: 94). See also the case of Susanna in the Apocrypha (Susan and Daniel 1-64). 
does not show masculine bias in any way. He gives the right judgement by saying "if you have not sinned before, be the first to cast the stone at her". With the exception of the accused, all are men, yet they are all sinners like the woman. The conversation between the woman and Jesus demonstrates Jesus' respect for both men and women.

The third issue is how Deuteronomy 22:22 and John 8:1-11 can be applied in an African Urhobo cultural context. In the seven cases in Deuteronomy as presented by Thomas L. Constable above, we cannot but conclude that the cultural milieus were patriarchal-centered (Constable 2017:97-99). The woman was at the centre of injustice and oppression. However, her integrity is tainted and her life in danger. The same scenario is present in Urhoboland. The Urhobo cultural setting is also patriarchal in nature. A married woman is not allowed to be held by the hand by another man, as this is interpreted as adultery. Even though Deuteronomy 22:22 prescribes capital punishment for both a man and woman caught in the act of adultery, the woman is the one subjected to the process of proving her innocence. If she is unable to prove her innocence, she will be killed. Those who bring the woman to Jesus for judgment erred when they excused the man, demonstrating female oppression. This same oppression is prevalent in Urhobo culture. It has also been noted that "a major consensus among scholars and students of ancient studies is that women in ancient times were second class, oppressed, and subservient to men" (Bradley2003:4). The narrative in John 8:1-11 supports this conclusion as the men accuse only the woman caught in the act of adultery and allowed the man to go free. In the Urhobo cultural setting, women are very vulnerable to oppression and injustice. While a husband has the right to have concubines, a woman may not even hold hands with another man. If a man is caught with another man's wife, the man is severely punished in terms of paying damages, but the woman suffers more humiliation in terms of stigma and deprivation. The husband of the adulteress may divorce her with immediate effect, but the male culprit pays the stipulated fine and continues with his life without any stigma attached to him and without fear of endangering his marriage.

\section{Conclusion}

Focusing on reading Deuteronomy 22:22 in John 8:1-11 within the Urhobo cultural context, the paper has shown how Deuteronomy 22:22 and John 8:1-11 constitute injustice to and oppression of women. The paper has also shown a nexus between the text and the Urhobo cultural narrative on sexuality especially as it concerns treatments accorded to women and men in Jewish and Urhobo cultural milieus. The paper has demonstrated that women are accorded low status in both cultural settings. Some nuances in the text have been identified: grammatical nuances, enactment and implementation nuances, historical distortion nuances and differing intentions nuances.

Specifically in terms of adultery the consequences are much more severe for women in the text in John 8:1-11 and in the current Urhobo cultural context. There is a gulf of inequality between men and women in Urhoboland similar to the situation in John 8:111 , where the adulterous man is excused, and the woman is brought for punishment. The church is being challenged to speak and create more awareness of the need to treat men and women with equity, fairness and justice. Adultery should be discouraged irrespective of gender. This also poses a challenge for the church and her leadership to examine and re-examine the church community and the society at large to address how women are 
oppressed, also sexually. For instance, in Nigeria today, some tribes, including the Urhobo, still practise female genital mutilation (FGM)on the grounds of taming the sexual desire of women so as to forestall any tendencies to promiscuity. Depriving women of enjoying sexual pleasure, is oppression. This is an aspect of sexuality research I would love to recommend for further research.

\section{BIBLIOGRAPHY}

Acquaye, D.K. et al. 1974. African encyclopedia for schools and colleges. Oxford: Oxford University Press.

Adamo, D.T. 1999. African cultural hermeneutics. In Sugirtharajah, R.S. (ed.), Vernacular hermeneutics. Sheffield: Sheffield Academic Press.

Adamo, David T. 2001. Reading and interpreting the Bible in African Indigenous Churches. Eugene, Oregon: WIPF and Stock Publishers.

Ademiluka, S.O. 2013. The prohibition of cross-dressing in Deuteronomy 22:5 as a basis for the controversy among churches in Nigeria on female wearing of trousers, Old Testament Essays 26 (1):9-19. Available online: http://www.scielo.org.za/scielo.php?script=sci_arttext\&pid=S101099192013000100001. Accessed January 26, 2018.

Akpomuvie, Orhioghene B. 2009. Rural development and socio-cultural associations in Nigeria: Findings from Urhoboland, Delta State, Nigeria, International Journal of Research in Arts and Social Sciences 1:92-111.

Alland, N. (ed.). 1981. Textual critical apparatus on John 8:1-11 in Greek English New Testament. Stuttgart: Deutsche Bibelgesellschaft.

Alexander, D. and Alexander, P. 1982. The Lion handbook to the Bible. Oxford: Lion Publishing Plc.

Amram,David W. 1906.Adultery. In Singer, I (ed.), Jewish Encyclopaedia (Vol.1). New York and London: Funk \& Wagnalls Company, 216-219. Available online: http://www.jewishencyclopedia.com/articles/865-adultery. Accessed February 5, 2018.

Anum, Eric. 2000. Comparative readings of the Bible in Africa: some concerns. In West, G.O. and Dube. M. (eds), The Bible in Africa: transactions, trajectories and trends. Leiden: E.J. Brill.

Aune, David E. 1988. The New Testament in its literary environment. Cambridge: James Clarke \& Co.

Aweto, Albert O. and Igben, Jomata L.2003. Geography of Urhoboland. In Otite, O. The Urhobo people. Ibadan: Shaneson C.I. Ltd.

Baroody, Wilson G. and Gentrup, William F. 2010. Exodus, Leviticus, Numbers and Deuteronomy. In Ryken, L. and Longman, T. III (eds), A complete literary guide to the Bible. Grand Rapids, MI: Zondervan, 121-136.

Baum, Armin D. 2014. Does the Pericope Adulterae (John 7:53-8:11) have canonical authority? An interconfessional approach, Bulletin for Biblical Research 24 (2):163-178. 
Bible.org, 2017. 11. Exegetical commentary on John 8. Available online: https://bible.org/seriespage/11-exegetical-commentary-john-8\#P1715_281744. Accessed December 29, 2017.

Bromiley,Geoffrey W. et al.(eds). 1979.The International Standard Bible Encyclopedia (Vol. 1). Grand Rapids: Wm. B. Eerdmans Publishing.

Bradley,Carol P. 2003. Women in Hebrew and Ancient Near Eastern law, Studia Antiqua 3(1):3-45.

Burgon, J.W. 1896. The cause of the corruption of the traditional text of the Holy Gospel. Cambridge: Deighton.

Constable, Thomas L. 2017. Notes on Deuteronomy. Available online: http://www.soniclight.com.

Draper, Jonathan A. 2001. Old scores and new notes: where and what is contextual exegesis in the new South Africa? In Speckman, M.T. and Kaufmann, L.T. (eds), Towards an agenda for contextual theology: essays in honour of Albert Nolan. Pietermaritzburg: Cluster Publications, 148-168.

Edenburg, C. 2009. Ideology and social context of the Deuteronomic women's sex laws (Deuteronomy 22:13-29), Journal of Biblical Literature 128(1):43-60.

Encarta, 2009. Deuteronomy. In Microsoft® Encarta® 2009. (C) 1993-2008 Microsoft Corporation.

Fee, Gordon D. 1993. Textual criticism of the New Testament. In Studies in the theory and method of New Testament textual criticism. Grand Rapids, MI: Eerdmans.

Gench, Frances Taylor. 2009.John 7:53-8:11, Interpretation: A Journal of Bible and Theology63(4):398-400.

Gower, Ralph. 1973/83. Everyday life in Bible times. In Alexander, D. and Alexander, P. (eds), The Lion Handbook to the Bible. London: Lion Publishing House.

GradeSaver, 2018. An overview of literary genres. Available online: http://www.gradesaver.com/writing-help/an-overview-of-literary-genres. Accessed January2, 2018.

Gundry, Robert H. 1981. A survey of the New Testament. Grand Rapids: Zondervan Publishing House.

Hengel, Martin. 1989. The Johannine question. London: Scm Press.

Hodges, Z.C. 1979. The woman taken in adultery (John 7:53-8:11): The text, BibSac 136:318-332.

Holter, Knut. 2002. Old Testament research for Africa: a critical analysis and annotated bibliography of African Old Testament dissertations, 1967-2000. New York: Peter Lang.

Ibodje, S.W.E. 2009. The challenges of the Urhobo nation. A paper presented at Urhobo Unity Summit, 2009, held at the P.T.I Conference Centre, Effurun, July 31. Available online:

http://www.waado.org/Organizations/UPU/urhobo_unity_summit_2009/ibodje_ch allenges.htm\#_ftn1. Accessed November 6, 2017.

Kaiser Walter C. Jr. 1983. Toward Old Testament ethics. Grand Rapids: Zondervan Publishing House.

Kaufman, Stephen A. 1978-79. The structure of the Deuteronomic Law, MAARAV $1: 105-58$. 
Keith, Chris. 2009. The Pericope Adulterae, the Gospel of John, and the Literacy of Jesus. Leiden: Brill.

Kirsch, Adam. 2018. Virgin brides, premarital sex, and Jewish patriarchal ownership of female bodies. Available online: http://www.tabletmag.com/jewish-life-andreligion/188846/daf-yomi-115-kirsch. Accessed February 5, 2018.

Krejcir, Richard J. 2006. Genres in the Bible. Available online: http://www.intothyword.org/apps/articles/default.asp?articleid=31435. Accessed January 2, 2018.

Mbuvi, Andrew M. 2017. African Biblical Studies: An introduction to an emerging discipline, Currents in Biblical Research 15(2):149-178. Available online: https://doi.org/10.1177/1476993X16648813.

Meenan, Alan J. 2014. Biblical hermeneutics in an African context, The Journal of Inductive Biblical Studies 1(2):268-273.

Merrill, Eugene H. 1994. Deuteronomy, New American Commentary series NAC. Nashville, TN: Broadman \& Holman Publishers.

Metzger, Bruce M. 1971. A textual commentary on the Greek New Testament. New York: United Bible Societies.

Nasimiyu-Wasike, A. 1992. Polygamy: A feminist critique. In Oduyoye, M.A. and Kanyoro, M.R.A. (eds), The will to arise: Women,tradition and the Church in Africa. Maryknoll: Orbis Books, 101-118.

Nelson, Richard D. 2004. Deuteronomy: A commentary. Louisville: Presbyterian Publishing Corp.

Ngewa, Samuel M. 2003. The Gospel of John for pastors and teachers. Nairobi: Evangel Publishing House.

Oduyoye, M.A. 1994.Violence against women: A challenge to Christian Theology, Journal of Inculturation Theology 1:38-53.

Okure, T. 1988. Women in the Bible.In Fabella, V. and Oduyoye, M.A. (eds), Passion and compassion: Third world women doing Theology. Maryknoll: Orbis Books, 47-59.

Ottuh, John A. 2014. The Urhobo traditional justice system in relation to adultery in the light of John 8:1-11: A feminist approach, Journal of Research in Humanities and Social Science 2(3):61-74.

Palmer, Earl F. 1999. The book that John wrote. Vancouver, BC: Regent College Publishing.

Penner, Jeremy S. 2003. Legal witnessing in the Dead Sea Scrolls: Maintaining purity and holiness. Unpublished MA thesis, Seton Hall University. Available online: https://scholarship.shu.edu/dissertations/2424.

Queen-Sutherland, K. 2016. Deuteronomy and adultery: A commandment to live free, Review \& Expositor 113(4):501-512.

Rabin, C., Leiter, S. and Abramson, Glenda M. 2013. Hebrew literature. In Encyclopaedia Britannica. Available online: https://www.britannica.com/art/ Hebrew-literature\#ref107410. Accessed January 2, 2018.

Reeder, Caryn A. 2013. Wives and daughters: Women, sex, and violence in Biblical tradition,Ex Auditu: An International Journal for the Theological Interpretation of Scripture 28:122-141. 
Robinson, George L. 1939. Deuteronomy. In Orr, J. (ed.), International Standard Bible Encyclopedia Online. Grand Rapids: Wm. B. Eerdmans Publishing Co. Available online: http://www.internationalstandardbible.com/D/ deuteronomy.html. Accessed January 23, 2018.

Shepherd, Massey H. Jr. 1990. The Gospel according to John. InThe Interpreter's OneVolume Commentary on the Bible. Nashville: Abingdon Press, 143-157.

Sproul, Robert C. 1977. Knowing Scripture. Downers Grove, Illinois: InterVarsity Press.

Thomaskutty, J. 2015. Dialogue in the Book of Signs: A polyvalent analysis of John 1:19-12:50. Leiden: Brill.

Ukpong,Justin S. 1999. Can African Old Testament scholarship escape the historical critical approach? Newsletter on African Old Testament Scholarship 7:2-5.

Ukpong, Justin S. 2000. Developments in biblical interpretation in Africa: Historical and hermeneutical directions. In West G.O. and Dube, M. (eds), The Bible in Africa: transactions, trajectories and trends. Leiden: E.J. Brill.

Ukpong, Justin S. 2002. Inculturation hermeneutics: An African approach to Biblical interpretation. In Dietrich, Walter and Luz, Ulrich (eds), The Bible in aworld context: An experiment in contextual hermeneutics. Grand Rapids, Michigan/Cambridge: William B. Eerdmans Publishing Company, 17-32.

West, Gerald O. 2010. Biblical hermeneutics in Africa. In Stinton, D.B. (ed.), African theology on the way: Current conversations. London: SPCK, 21-31. Available online: http://www.chora-trangers.org/files/chora/west2008_Parratt.pdf. Accessed December 28, 2017.

Westbrook, R. 2008. The laws of Biblical Israel. In Greenspahn, Frederick E. (ed.), The Hebrew Bible: New insights and scholarship. New York: New York University Press, 99-119.

Wood, Maureen M. 2013. A dialogue on feminist Biblical hermeneutics: Elisabeth Schüssler Fiorenza, Musa Dube, and John Paul II on Mark 5 and John 4. Unpublished MA thesis, University of Dayton.

Young, G. 2013. Deuteronomy-Biblical literature. In Encyclopaedia Britannica. Available online: https://www.britannica.com/topic/Deuteronomy. Accessed January 2, 2018. 